\section{EFFECT OF HEAT WAVE ON THE INDIAN FLYING FOX Pteropus giganteus (Mammalia: Chiroptera: Pteropodidae) POPULATION FROM PURULIA DISTRICT OF WEST BENGAL, INDIA}

\author{
Somenath Dey ${ }^{1}$, Utpal Singha Roy ${ }^{2} \&$ Sanjib Chattopadhyay ${ }^{3}$ \\ ${ }^{1}$ P.G. Department of Zoology, Darjeeling Government College, 19, Lebong Cart Road, Darjeeling, West Bengal 734101, \\ India \\ ${ }^{2}$ Department of Zoology, Durgapur Government College, J.N. Avenue, Durgapur, Burdwan, West Bengal 713214, India \\ ${ }^{3}$ Panchakot Mahavidyalaya, Sarbari, Neturia, Purulia, West Bengal 723121, India \\ ${ }^{1}$ somenath.prl@gmail.com, ${ }^{2}$ srutpal@gmail.com (corresponding author), ${ }^{3}$ csanjibrng@gmail.com
}

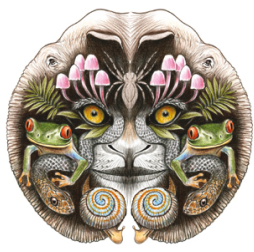

ISSN 0974-7907 (Online) ISSN 0974-7893 (Print)

OPEN ACCESS
Abstract: The present study was undertaken to examine the effect of heat wave on the behavior and population count of Indian Flying Fox Pteropus giganteus from a roosting colony occupying a Tamarind tree Tamarindus indica at Simla Village of Purulia District of West Bengal, India during the period from March 2010 to July 2010. A total population comprising 250 individuals, recorded in March 2010, came down to 80 by June 2010. Information obtained from local villagers affirmed that the roosting bat colony from the present study location was a century old and had no apparent conflicts with villagers; moreover, it was protected with reverence. However, soaring day temperatures (with a maximum of up to $48^{\circ} \mathrm{C}$, recorded during May and June 2010) alongside drought were the major threats that the population faced and mass die-offs caused the population to decline during the hotter months. Continuous fanning and belly-soaking were common behavioural features recorded during the summer months. However, death rate due to hyperthermia and dehydration was uncommonly high.

Keywords: Drought, heat wave, mass death, Pteropus giganteus.
Climate changes expose organisms to novel environmental conditions with the potential to affect the life history and demography of individuals. If they are to stay alive and reproduce, organisms must cope with such environmental changes. After all, how well a species is able to cope with environmental changes depends on its potential to adapt to new environmental conditions. Changes in climate are significant for natural systems as they can affect population abundance, shifts in species range distribution and the number of species invasion and extinction (Parmesan \& Yohe 2003; Thomas et al. 2004). Recently, extreme weather events have gained importance as mechanistic drivers of broad ecological changes (Parmesan et al. 2000). A
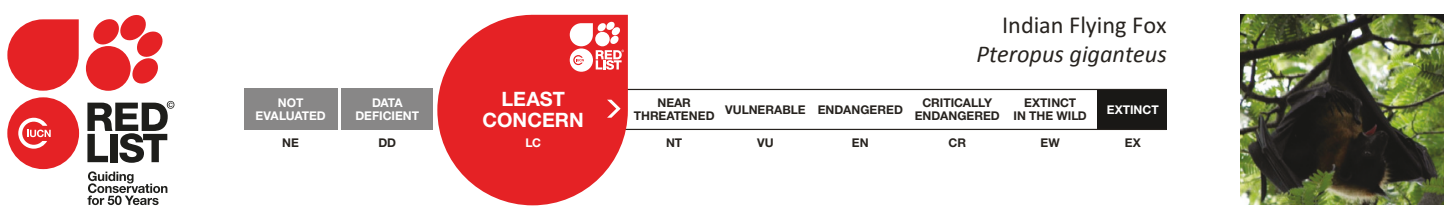

DOI: http://dx.doi.org/10.11609/JoTT.03947.7029-33

Editor: C. Srinivasulu, Osmania University, Hyderabad, India.

Date of publication: 26 March 2015 (online \& print)

Manuscript details: Ms \# 03947 | Received 19 February 2014 | Final received 11 January 2015 | Finally accepted 06 March 2015

Citation: Dey, S., U.S. Roy \& S. Chattopadhyay (2015). Effect of heat wave on the Indian Flying Fox Pteropus giganteus (Mammalia: Chiroptera: Pteropodidae) population from Purulia District of West Bengal, India. Journal of Threatened Taxa 7(3): 7029-7033; http://dx.doi.org/10.11609/JoTT.03947.7029-33

Copyright: (c) Dey et al. 2015. Creative Commons Attribution 4.0 International License. JoTT allows unrestricted use of this article in any medium, reproduction and distribution by providing adequate credit to the authors and the source of publication.

Funding: University Grants Commission (Minor Research Project, Sanction No. F. PSW-037/09-10(ERO), Dated: 26 ${ }^{\text {th }}$ October, 2009), New Delhi, India.

Competing Interest: The authors declare no competing interests

Acknowledgements: This work was a part of Minor Research Project and authors acknowledge University Grants Commission, New Delhi, India for providing necessary funds. Authors are thankful to the local inhabitants of Simla village for their immense and unconditional help and cooperation. Authors also acknowledge the help and cooperation extended by the Director of Public Instruction, Government of West Bengal, Kolkata. Somenath Dey is thankful to Dr. Lalita Rai Ahmed, Principal, Darjeeling Government College, Darjeeling, West Bengal, India; Utpal Singha Roy is thankful to Prof. A.K. Pal, Officer-in-Charge, Durgapur Government College, West Bengal for their keen interest in the present work. Authors acknowledge the help and support provided by District Forest Office, Kangsabati Division, Purulia. 
global increase in temperature between the average of 1850-1900 and the 2003-2012 periods has been approximated to be 0.78 ( 0.72 to 0.85 ) ${ }^{\circ} \mathrm{C}$ (IPCC 2013). Climate change is presumed to be the greatest threat to biodiversity in the coming decade with mid-range climate changes expected to force greater extinction rates than habitat loss, which is currently deemed the top threat to biodiversity (Thomas et al. 2004). Temperature extremes that exceed physiological limits can cause widespread mortality including humans (WHO 2003). The Indian Flying Fox Pteropus giganteus is a fruit bat of the suborder Megachiroptera of the order Chiroptera (Simmons 2005; Srinivasulu \& Srinivasulu 2012). Fruit bats forage for fruits, nectar and pollen at night and roost on trees (their camp) in hundreds during the day. The roosting tree is usually situated on the side of a water body (Dey \& Chattopadhyay 2011; Dey et al. 2013). Fruit bats provide an important ecosystem service including the pollination of wild and cultivated crops, and seed dispersal (Fujita \& Tuttle 1991). Because flying foxes roost among exposed branches of high trees, they are particularly susceptible to the effects of extreme temperatures. Therefore, the species is a convenient indicator for assessing the impact of extreme temperatures on natural systems (Welbergen et al.
2008). Thus the objective of the study was to examine the effects of the heat wave and associated drought on a population of the Indian Flying Fox in West Bengal.

\section{MATERIALS AND METHOdS}

Study area: The present study was undertaken at Simla Village $\left(23^{\circ} 22^{\prime} 44.20^{\prime \prime} \mathrm{N} \& 86^{\circ} 38^{\prime} 47.02^{\prime \prime} \mathrm{E}\right)$ of Purulia District, on the side of Adra-Hura Road, about $18 \mathrm{~km}$ from the busy Adra Railway Town. The camp is on a Tamarind Tree Tamarindus indica close to water bodies (Fig. 1).

Data collection: Surveys were conducted twice a month at the camp between March 2010 and July 2010. The census was done applying the direct roost count method (Barlow 1999) at 08:00hr, 12:00hr and 16:00hr. The bat population was counted three times during each sampling using binoculars and a digital camera, and numbers were averaged to get a representative value. Additionally, bats emerging from the roosting site during the sunset were photographed and counted (O'Shea et al. 2003). Observations on bat behaviour were done using binoculars and digital cameras in addition to the bat population census. Studies on bat behaviour were conducted for a span of one hour which comprised 10 minutes of observation and 10 minutes
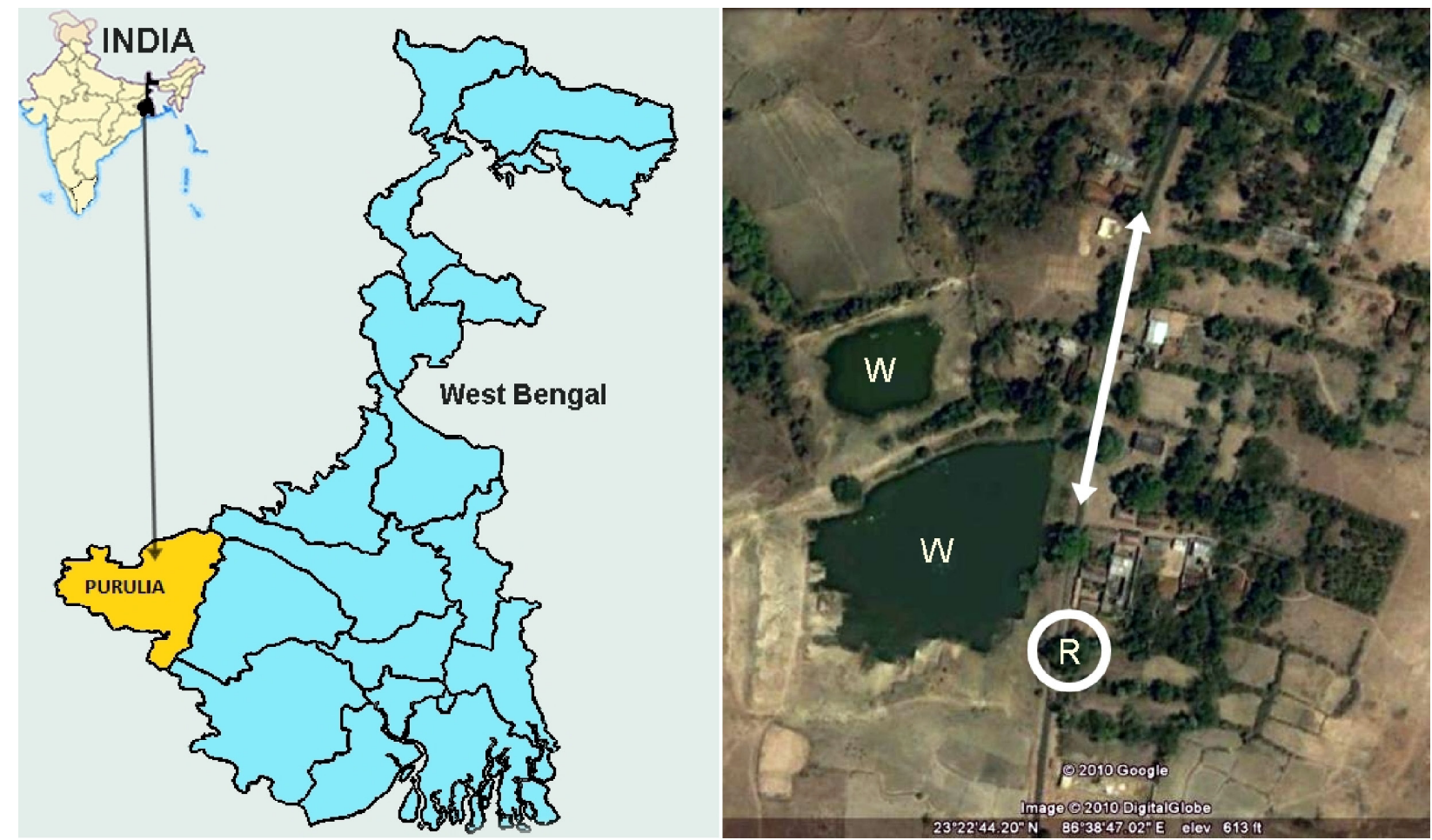

Figure 1. Map showing the study site under present investigation from SimlaVillage of Purulia District, West Bengal, India. Circle with ' $R$ ' indicates the bat colony roosting site; Arrow indicate Adra-Hura Road; W = water body. 
of intermission at $08: 00 \mathrm{hr}, 12: 00 \mathrm{hr}$ and $16: 00 \mathrm{hr}$. The ambient temperature was noted at regular intervals (at 08:00hr $12: 00 \mathrm{hr}$ and $16: 00 \mathrm{hr}$ ) to get a representative mean value. The temperature was recorded by using a digital thermometer (CIE310), holding the probe $2 \mathrm{~m}$ above the ground. Recordings were made both in light and shaded areas near the roosting tree and averaged. The mean values recorded for a single month were crosschecked with data obtained from the District Forest Office, Kangsabati Division, Purulia.

The data on deaths of bats due to the heat wave were gathered through interviewing locals of Simla Village.

Statistical analysis: A statistical analysis to test for a correlation between the bat population size, ambient temperature and number of dead bats $(p<0.05)$ was performed using the statistical software Statistica for Windows, vers. 5.1A (Statsoft 1996).

\section{RESULTS}

The monthly maximum and minimum temperatures $\left({ }^{\circ} \mathrm{C}\right)$, population count and the number of dead bats recorded during the five months of the study period are presented in Table 1. During March 2010, the temperature was rising (with the maximum temperature recorded at $38^{\circ} \mathrm{C}$ ) and bats were found to show two basic thermoregulatory behaviors, viz., wing fanning and seeking shade during mid noon (Image 1). From April onwards (with the maximum temperature having crossed $45^{\circ} \mathrm{C}$ ), they were repeatedly found panting (Image 2) and belly soaking (Image 3). During the hottest hours, the sampling bats were recorded soaking their bellies two to three times within a study span of one hour. A few bats were found to make a local migration to the nearby remnants of forest patches during the hotter months and returned to their roosting camp in July 2010, when the temperature came down to $42^{\circ} \mathrm{C}$, increasing

Table 1. Abundance of Indian Flying Fox Pteropus giganteus population along with the number of dead bats and ambient temperatures (both maximum and minimum) recorded from March 2010 to July 2010 from Simla village of Purulia District, West Bengal, India.

\begin{tabular}{|l|c|c|c|c|}
\hline \multirow{2}{*}{ Month } & \multicolumn{2}{|c|}{ Temperature $\left({ }^{\circ} \mathrm{C}\right)$} & \multirow{2}{*}{$\begin{array}{c}\text { Population size } \\
\text { of bats }\end{array}$} & $\begin{array}{c}\text { Number of } \\
\text { dead bats }\end{array}$ \\
\cline { 2 - 3 } Maximum & Minimum & 250 & 00 \\
\hline March & 38 & 26 & 180 & 30 \\
\hline April & 46 & 33 & 90 & 20 \\
\hline May & 48 & 35 & 80 & 06 \\
\hline June & 48 & 34 & 120 & 00 \\
\hline July & 42 & 26 & & \\
\hline
\end{tabular}

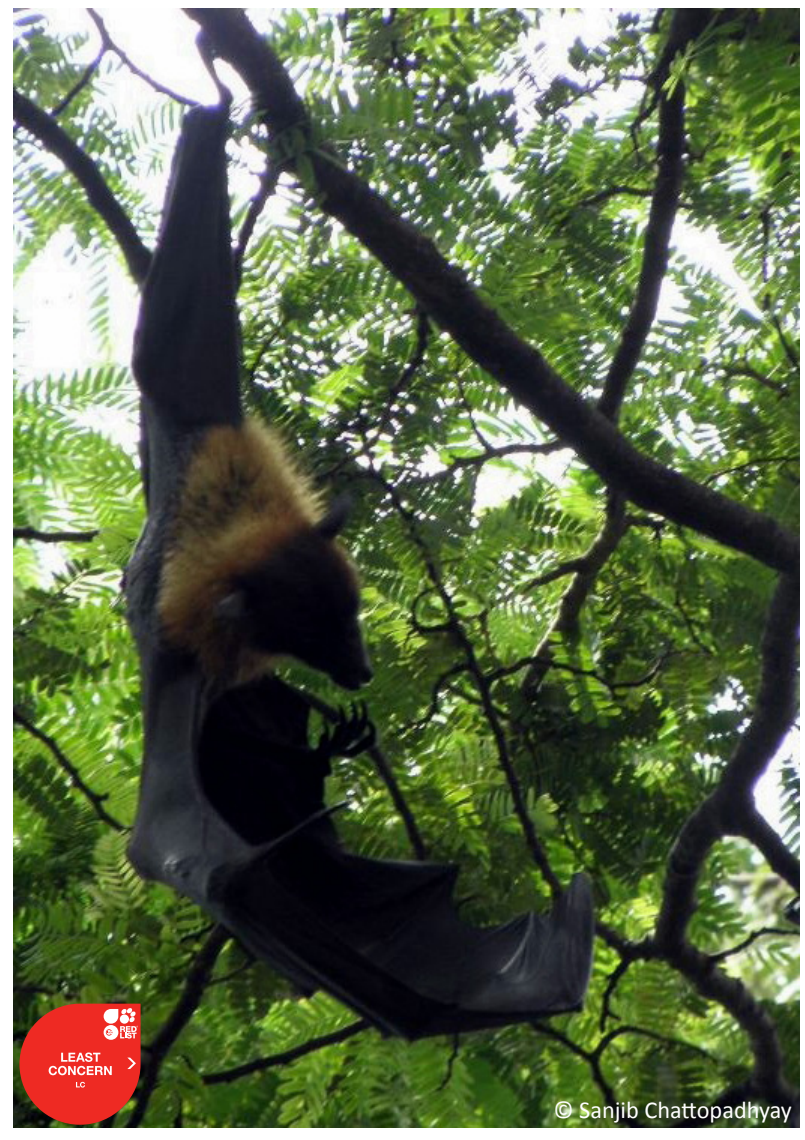

Image 1. Bat showing stretching and fanning behaviour of patagium to avoid excessive ambient temperature.

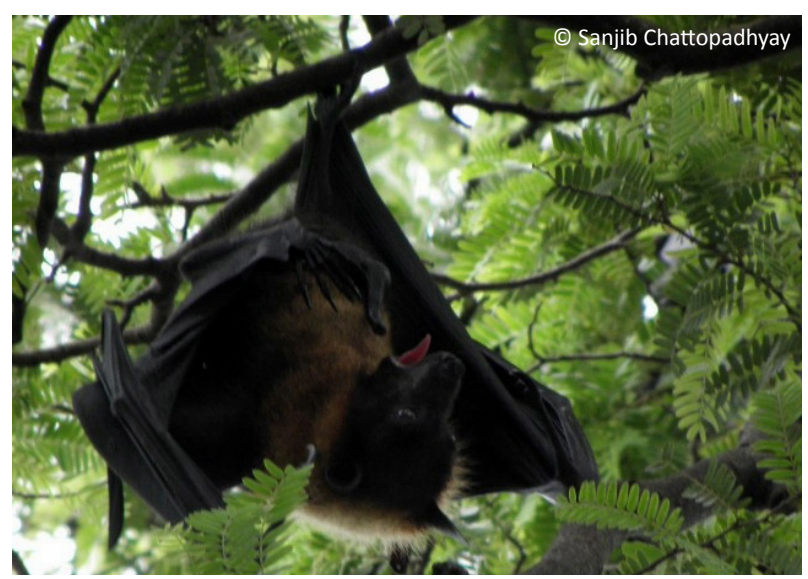

Image 2. Panting behaviour as a part of thermoregulatory mechanism shown by bats from the present study location.

the total population count (Table 1). However, as the ambient temperature crossed the tolerance limit with most of the water bodies having dried up, the bats were found to become lethargic in their behaviour and those who failed to migrate to alternative cooler roosting sites, eventually died (Image 4). Correlation 


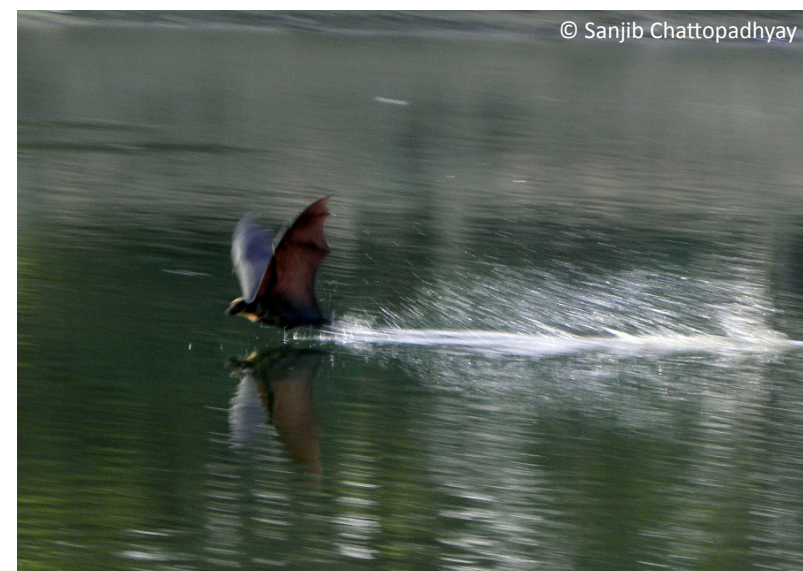

Image 3. Bat displaying the belly-soaking activity as a part of the thermoregulatory mechanism to avoid extreme temperatures.

matrices revealed a negative relationship (Pearson's $r$ $-0.71, p<0.05)$ between bat abundance and ambient temperature, while a positive correlation (Pearson's $r$ $0.68, p<0.05$ ) was found between the number of dead bats and ambient temperature.

\section{Discussion}

The present study clearly indicates that extreme high temperature has a profound effect on the Indian Flying Fox. At Purulia District, the temperature has been recorded to range from a maximum of $45^{\circ} \mathrm{C}$ to a minimum of $23^{\circ} \mathrm{C}$ during the summer while it is between a maximum of $20^{\circ} \mathrm{C}$ and a minimum of $3^{\circ} \mathrm{C}$ during the winter. Rainfall defined the average monthly temperature of the district. A lack of adequate rains during the summer months of 2010 were unusual in the last 10 years.

In their active state, fruit bats could maintain their body temperatures between $35^{\circ} \mathrm{C}$ and $39^{\circ} \mathrm{C}$ (Neuweiler 2000). Because the normal body temperature was close to the lethal value of $44-45{ }^{\circ} \mathrm{C}$ they were less able to protect themselves from overheating. If the ambient temperature $\left(T_{a}\right)$ was above the body temperature $\left(T_{b}\right)$, fruit bats displayed their thermoregulatory behaviors, which were adaptive for maintaining $T_{b}$ against $T_{a}$. When $T_{a}$ reached the lethal value, no thermoregulatory strategy was adequate for life support and bats became increasingly lethargic and ultimately died (Neuweiler 2000). The present findings were in accordance with the above explanations where intolerable ambient temperatures caused mass die-offs of fruit bats. Similar findings were also made by Welbergen et al. (2008) where temperature exceeding $42^{\circ} \mathrm{C}$ have been reported to kill more than 3500 individuals in a single day in nine

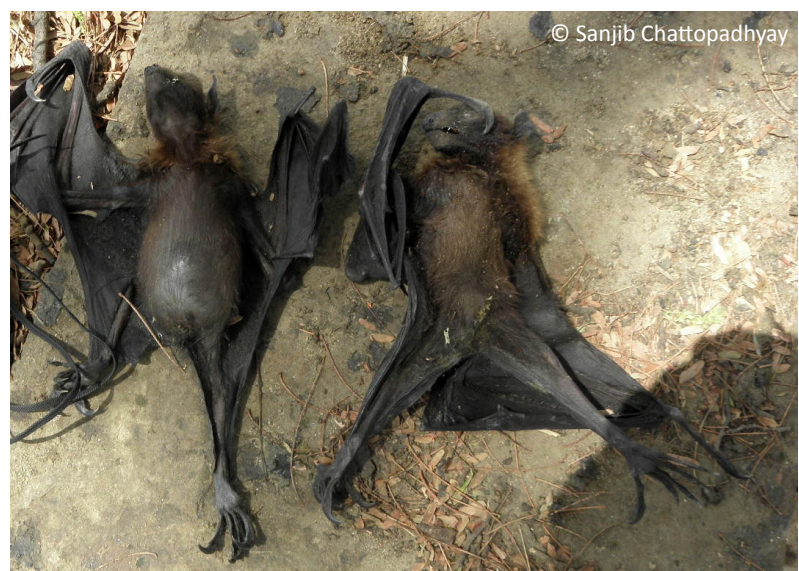

Image 4. A failure of thermoregulatory mechanisms eventually lead to death. Two dead bats shown in this figure had fallen from their roosting tree on to the ground.

mixed-species colonies of wild flying-foxes (Pteropus spp.) from New South Wales, Australia. However, mention may be made that a small fraction of the bat population from the present study location made local migrations to take shelter in relatively cooler forested regions and returned to their original roosting site when the ambient temperature came down. Climate change has been predicted to have profound impacts on the natural environment, and the present study has provided an example of how high temperature and associated drought might affect the survival of fruit bats. Rising heat, therefore, most certainly poses a great threat to the survival of Indian flying foxes and the ecological services they provide.

Ecological services including seed dispersal and pollination, provided by bats are immense and well established (Fleming \& Estrada 1993; Banack 1998; Shiltonet al. 1999; Godinez-Alvarez et al. 2002). Fruit bats have been reported to be engaged with the propagation of more than 300 plant species in the Old World (Marshall 1983; Fujita \& Tuttle 1991). However, most unfortunately Pteropus giganteus is presently listed as vermin under Schedule $\mathrm{V}$ of the Indian Wildlife (Protection) Act and belongs to the group of one of the most persecuted fruit bats in South Asia (Molur et al. 2002). Although the IUCN Red List of Threatened Species has classified this species as Least Concerned, the number of individuals have decreased consistently (Venkatesan 2007), primarily due to habitat loss and hunting. Accordingly, some populations are becoming locally Threatened (Molur et al. 2008). A 48\% decline in the Pteropus giganteus population from a single roosting site in Assam, India has been reported by Ali (2010) during his 10 years of study from 2001 to 2010. If 
there is one near-certainty about our changing climate, it is that, it is getting warmer. As this happens, climate models suggest that, once rare, heat waves will occur more often, and unheard of extremes will strike on occasion (Laurence 2010). We are concerned that if the summer of 2010 repeats in the coming years, it will drive this species to extinction, from this part of India. All concerned - conservationists, government and non-governmental agencies have a major role to play in creating public awareness and garnering support to protect and conserve the dwindling populations of the Indian flying fox.

\section{REFERENCES}

Ali, A. (2010). Population trend and conservation status of Indian Flying Fox Pteropus giganteus Brunnich, 1782 (Chiroptera: Pteropodidae) in western Assam. The Ecoscan 4(4): 311-312.

Banack, S.A. (1998). Diet selection and resource use by Flying Foxes (genus Pteropus). Ecology 79: 1949-1967; http://dx.doi. org/10.1890/0012-9658(1998)079[1949:DSARUB]2.0.CO;2

Barlow, K. (1999). Expedition Field Techniques: Bats. Expedition Advisory Centre, Royal Geographical Society, London, 69pp.

Dey, S. \& S. Chattopadhyay (2011). A population of Flying Foxes (Pteropus giganteus) treated as sacred and protected by villagers. Journal of Environment and Sociobiology 8(1): 115-118.

Dey, S., U.S. Roy \& S. Chattopadhyay (2013). Distribution and abundance of three populations of Indian Flying Fox (Pteropus giganteus) from Purulia District of West Bengal, India. Taprobanica 5(01): 60-66.

Fleming, T.H. \& A. Estrada (1993). Frugivory and Seed Dispersal: Ecological and Evolutionary Aspects. Kluwer Academic Publishers, Dordrecht, The Netherlands, 392pp.

Fujita, M.S. \& M.D. Tuttle (1991). Flying Foxes (Chiroptera: Pteropodidae): threatened animals of key ecological and economic importance. Conservation Biology 5: 455-463; http://dx.doi. org/10.1111/j.1523-1739.1991.tb00352.x

Godinez-Alvarez H., A. Valiente-Banuet \& A. Rojas-Martinez (2002). The role of seed dispersers in the population dynamics of the columnar cactus Neobuxbaumia tetetzo. Ecology 83: 2617-2629; http://dx.doi.org/10.1890/0012-9658(2002)083[2617:TROSDI]2.0. $\mathrm{CO} ; 2$

IPCC (2013). Summary for Policymakers. In: Stocker, T.F., D. Qin, G.K. Plattner, M. Tignor, S.K. Allen, J. Boschung, A. Nauels, Y. Xia, V. Bex \& P.M. Midgley (eds.). Climate Change 2013: The Physical Science Basis. Contribution of Working Group I to the Fifth Assessment Report of the Intergovernmental Panel on Climate Change. Cambridge University Press, Cambridge, United Kingdom and New York, NY, USA.
Laurence, W. (2010). Climate shock: One heat wave from oblivion. New Scientist 2789: 37-39.

Marshall, A.G. (1983). Bats, flowers and fruit: evolutionary relationships in the Old World. Biological Journal of the Linnean Society 20: 115-135; http://dx.doi.org/10.1111/j.1095-8312.1983. tb01593.x

Molur, S., G. Marimuthu, C. Srinivasulu, S. Mistry, A.M. Hutson, P.J.J. Bates, S. Walker, K. Padma Priya and A.R. Binu Priya (2002). Status of South Asian Chiroptera: Conservation Assessment and Management Plan (C.A.M.P.) Workshop Report, 2002. Zoo Outreach Organisation, CBSG South Asia and WILD, Coimbatore, India, CDRom.

Molur, S., C. Srinivasulu, P. Bates \& C. Francis (2008). Pteropus giganteus. In: IUCN 2012. IUCN Red List of Threatened Species. Version 2012.2. <www.iucnredlist.org>. Downloaded on 18 October 2012.

Neuweiler, G. (2000).The Biology of Bats. Oxford University Press, UK, 310pp.

O'Shea, T.J., M.A. Bogan \& L.E. Ellison (2003). Monitoring trends in bat populations of the United States and territories: status of the science and recommendations for the future. Wildlife Society Bulletin 31: 16-29.

Parmesan, C., T.L. Root \& M.R. Willig (2000). Impacts of extreme weather and climate on terrestrial biota. Bulletin of the American Meteorological Society 81: 443-450.

Parmesan, C. \& G. Yohe (2003). A globally coherent fingerprint of climate impacts across natural system. Nature 421: 37-42; http:// dx.doi.org/10.1038/nature01286

Shilton, L.A., J.D. Altringham, S.G. Compton \& V. Whittaker (1999). Old World fruit bats can be long-distance seed dispersers through extended retention of viable seeds in the gut. Proceedings of Royal Society of London B 266: 219-223.

Simmons, N.B. (2005). Order Chiroptera. In: Wilson, D.E. \& D.M. Reeder (eds.). Mammal species of the World: A Taxonomic and Geographical Reference - $3^{\text {rd }}$ Edition. Smithsonian Institution Press, Washington D.C.

Srinivasulu, C. \& B. Srinivasulu (2012). South Asian Mammals, Their Diversity, Distribution and Status. Springer, New York, xii+467pp.

Thomas, C.D., A. Cameron, R.E. Green, M. Bakkenes, L.J. Beaumont, Y.C. Collingham, B.F.N. Erasmus, M.F. De Siquiera, A. Grainger, L. Hannah, L. Hughes, B. Huntley, A.S. van Jaarsveld, G.F. Midgley, L. Miles, M.A. Ortega-Huerta, A.T. Peterson, O. Phillips \& S.E. Williams (2004). Extinction risk from climate change. Nature 427: 145; http://dx.doi.org/10.1038/nature02121

Venkatesan, A. (2007). Status of the Indian Flying Fox (Pteropus giganteus) in Bengaluru. BAT NETCCINSA Newsletter 8(1): 13-15.

Welbergen, J.A., S.M. Klose, N. Markus \& P. Eby (2008). Climate change and the effects of temperature extremes on Australian Flying Foxes. Proceedings of Royal Society of London B275: 419-442. WHO (2003). WHO briefing note for the fifty-third session of the WHO Regional Committee for Europe, 8-11pp. 